\title{
Nest-Building Behaviour by Chimpanzees (Pan troglodytes verus) in the Non-Protected Area of Diaguiri (Kedougou, Senegal): Implications for Conservation
}

\author{
Papa Ibnou Ndiaye $^{\mathrm{a}}$ Landing Badji $^{\mathrm{a}}$ Stacy Marie Lindshield ${ }^{\mathrm{b}, \mathrm{c}}$ \\ Jill D. Pruetz ${ }^{b, d}$ \\ ${ }^{a}$ Département de Biologie animale, Faculté des Sciences et Techniques, Université \\ Cheikh Anta Diop de Dakar, Dakar, Senegal; ${ }^{\mathrm{b}}$ Department of World Languages and \\ Cultures, Anthropology Program, lowa State University, Ames, IA, USA; 'Department of \\ Anthropology, Purdue University, West Lafayette, IN, USA; ${ }^{d}$ Department of Anthropology, \\ Texas State University, San Marcos, TX, USA
}

\section{Keywords}

Conservation - Diaguiri - Nesting behaviour - Nest decay rate $\cdot$ Pan troglodytes verus S Savanna chimpanzee

\begin{abstract}
Diaguiri is a non-protected area situated in south-eastern Senegal. Chimpanzees (Pan troglodytes verus) have been living here since 1999 but information on the characteristics of their nest sites have been lacking until now. Furthermore, we implemented nest survey methods recently standardised to arid landscapes during a national chimpanzee survey. Variations in nest decay rates are poorly understood in savanna-woodland mosaic habitats. This study aims to describe in Diaguiri: (1) the distribution of chimpanzee nests and the location of their core sleeping area, (2) the tree species used for nest building, (3) the association between nests and nesting tree heights, and (4) differences in nest decay rates between habitats. We surveyed $43 \mathrm{~km}$ of chimpanzee nesting habitats and recorded 871 nests in gallery forest and woodland habitats between March 2015 and June 2016. Diaguiri chimpanzees used at least 17 tree species for nest building, and $58.8 \%$ of nests were in only 3 tree species: Pterocarpus erinaceus, Anogeissus leiocarpus and Diospyros mespiliformis. Nest decay rate was faster in gallery forests than in woodlands. These data are of great value for understanding habitat use by a Critically Endangered subspecies of savanna chimpanzee, for population density estimates of the species and for conservation programmes in this region and in savanna biomes.
\end{abstract}

\begin{tabular}{l}
\hline KARGER $\odot 2018$ S. Karger AG, Basel \\
E-Mail karger@karger.com \\
www.karger.com/fpr
\end{tabular}

Papa Ibnou Ndiaye

Département de Biologie animale

Faculté des Sciences et Techniques

Université Cheikh Anta Diop de Dakar

Dakar (Senegal)

E-Mail ibnou.ndiaye@ ucad.edu.sn 


\section{Introduction}

Chimpanzees (Pan troglodytes) are listed as an Endangered species under the International Union for Conservation of Nature (IUCN) Global Species Programme [Oates et al., 2008]. The West African chimpanzee (P. t. verus) is one of the most threatened subspecies [Kormos and Boesch, 2003]; it was relisted as Critically Endangered in 2016 due to significant regional-wide population declines [Humle et al., 2016; Kühl et al., 2017]. Conserving these great apes requires a detailed understanding of their population size, spatial distribution and demographic trends. Survey and monitoring programmes are designed to provide this information. However, it is generally difficult to observe wild great apes in their natural habitat. Thus, nest count surveys are commonly used by researchers (1) to estimate great ape population sizes and (2) to determine habitats used for nesting and related aspects of nesting behaviour, especially for unhabituated apes [Pruetz et al., 2002; Kühl et al., 2008; Hernandez-Aguilar, 2009; Ukpong et al., 2013; Hakizimana et al., 2015; Dutton et al., 2016; McGrew, 2017].

Nest building behaviour may be a learned pattern in all great ape species. Weaned individuals of all great ape species build nests in which they sleep at night or sometimes rest during the day. Typically a nest is constructed, immediately used and abandoned the next morning [Kühl et al., 2008; Hernandez-Aguilar et al., 2013]. Nests can remain visible in the habitat for several weeks or months after construction and use. New nests are built each night, they may also be made during a mid-day rest [Kühl et al., 2008].

Chimpanzees show great selectivity for nest tree species, as they use only a subset of the total available tree species for nesting. Although no single characteristic has been found sufficient for explaining preferences in terms of nest tree species, nest tree selectivity has been linked generally to physical characteristics of the trees [Furnichi and Hashimoto, 2004; Hernandez-Aguilar, 2006; Ndimuligo, 2007; Stanford and O’Malley, 2008; Koops et al., 2012; Hernandez-Aguilar et al., 2013; Carvalho, 2014]. In light of the tremendous variation in nesting tree characteristics, managers of natural resources need to take account of information on nesting tree preference by chimpanzee populations. This information is of great help for the formulation of efficient conservation action plans. Thus, researchers must provide local information on nesting tree species, relationships between nest heights and tree heights, physical characteristics of the trees and the habitat types that chimpanzees preferentially use for nesting [Basabose and Yamagiva, 2002; Furnichi and Hashimoto, 2004; Hernandez-Aguilar, 2006; Ogawa et al., 2007; Hernandez-Aguilar, 2009; Koops et al., 2012; Ndiaye et al., 2013a, b; Ogawa et al., 2014; Hakizimana et al., 2015]. Chimpanzees use particular tree species for nest construction [Brownlow et al., 2001]. In the Nimba Mountains (Guinea), chimpanzees use $53.2 \%$ of the available tree species for nesting [Koops et al., 2012]. The 10 most frequently used species, namely Chidlowia sanguinea, Rinorea sp., Chrysophyllum africanum, Amanoa bracteosa, Santiria trimera, Ituridendron bequaertii, Bussea occidentalis, Synsepalum sp., Manilkara abovata and Drypetes afzelii, contained $56 \%$ of the nests. In the Boé area (Guinea), chimpanzees preferred to make their nests in Khaya senegalensis, Parkia biglobosa, Erythrophleum suaveolens and Cola cordifolia [Hoogveld, 2013]. In Lagoas de Cufada Natural Park, in Guinea, chimpanzees made $52.7 \%$ of their nests in Dialium guineense [Carvalho et al., 2015]. In Bagnomba (Senegal), 63\% of the chimpanzee nests were in Diospyros mespiliformis and Pterocarpus erinaceus [Badji et al., 2018]. Of the 123 available tree species in Mambilla Plateau in Tarabi State (Nigeria), the Nigerian/Cameroon chimpanzees 
(Pan troglodytes ellioti) use only $28.45 \%$ of the tree species for nesting. The top 5 identified nesting tree species were Anthonotha noldeae, Macaranga monandra, Strombosia scheffleri, Trichilia welwitschii and Isolona deightonii [Dutton et al., 2016]. In Bwindi National Park (Uganda), chimpanzees make nests in 38 of 163 tree species, and $72.1 \%$ of nests $(n=2,463)$ were constructed in just 4 species: Cassipourea sp., Chrysopyllum gorungosanum, Drypetes gerrardii and Teclea nobilis [Stanford and O’Malley, 2008]. Studies in Kibira National Park (Burundi) have focused on the environment and the characteristics of the trees used by chimpanzees for nesting and the type of habitat where nest sites are located [Hakizimana and Huynen, 2013; Hakizimana et al., 2015].

The numerous publications devoted to the nesting behaviour of chimpanzees clearly show its importance for the welfare and survival of this species. Studies of methods used to assess chimpanzee nesting behaviour in Budongo, Uganda, showed that different measures can have large effects on the estimation of chimpanzee density [Plumptre et al., 2003]. The key to accurately estimating population densities based on nesting behaviour is nest decay rate. Nest decay should be monitored in several areas if a large-scale census is being carried out because variation may occur at different sites and in different seasons [Kühl et al., 2008].

In Senegal, chimpanzees have adjusted to a hot, dry and open habitat [Pruetz et al., 2002, 2008]. While some studies have focused on nesting behaviour here [Stewart et al., 2007; Pruetz et al., 2008; Ndiaye et al., 2013a, b; Badji et al., 2018], most research has been done in the Niokolo Koba National Park (NKNP) or on the single habituated group at Fongoli outside the NKNP, but there have been no studies in the non-protected area of Diaguiri, Senegal. The Diaguiri chimpanzees live in an open and dry ecosystem that is intensively used by the local human population. For this reason, we studied their nesting behaviour to obtain scientific information specifically for the implementation of a conservation programme. Here we present the first data from Diaguiri on the nesting sites used by a population of chimpanzees never previously studied, and, in this non-protected area, we show the tree species used to nest in, the vertical distribution of the nests and the nest decay rate. These data are necessary to improve the conservation and management of chimpanzees in Diaguiri, specifically to inform policy on protecting key ecological aspects of the chimpanzees' natural environment.

\section{Material and Methods}

Study Site and Subjects

Our study was conducted in the hot, dry and open savanna of Diaguiri (UTM Zone 28N: 823230 E, 1396425 N) between March 2015 and June 2016. It is a non-protected area situated in the Kedougou region, outside NKNP, in the south-eastern region of Senegal (West Africa) (Fig. 1). Diaguiri is about $70 \mathrm{~km}$ from NKNP and $60 \mathrm{~km}$ from Bagnomba, and it has Sudano-Guinean types of climate and vegetation. It is a woodland-savanna mosaic landscape, which is mainly comprised of open-canopy habitats (woodland, bamboo woodland, grassland with scattered trees, treeless grassland) but also has small patches of closed-canopy (gallery forest, ecotone forest) habitat [Pruetz et al., 2008]. Diaguiri receives some of the highest rainfall levels within the country. From 1995 to 2014 , the annual rainfall ranged from 900 to $1,800 \mathrm{~mm}$, and the mean annual temperature was $28.6^{\circ} \mathrm{C}\left(\mathrm{t}_{\max } 35.4^{\circ} \mathrm{C}, \mathrm{t}_{\min } 21.9^{\circ} \mathrm{C}\right)$ [Agence Nationale de l'Aviation Civile et de la Météorologie de Sénégal (ANACIM), 2015]. The dry season occurs from November to April and the rainy season from June to October. During the rainy season, the gallery forests are flooded. The month of May is a transition point between the dry and the rainy seasons [Ndiaye et al., 2013b]. 


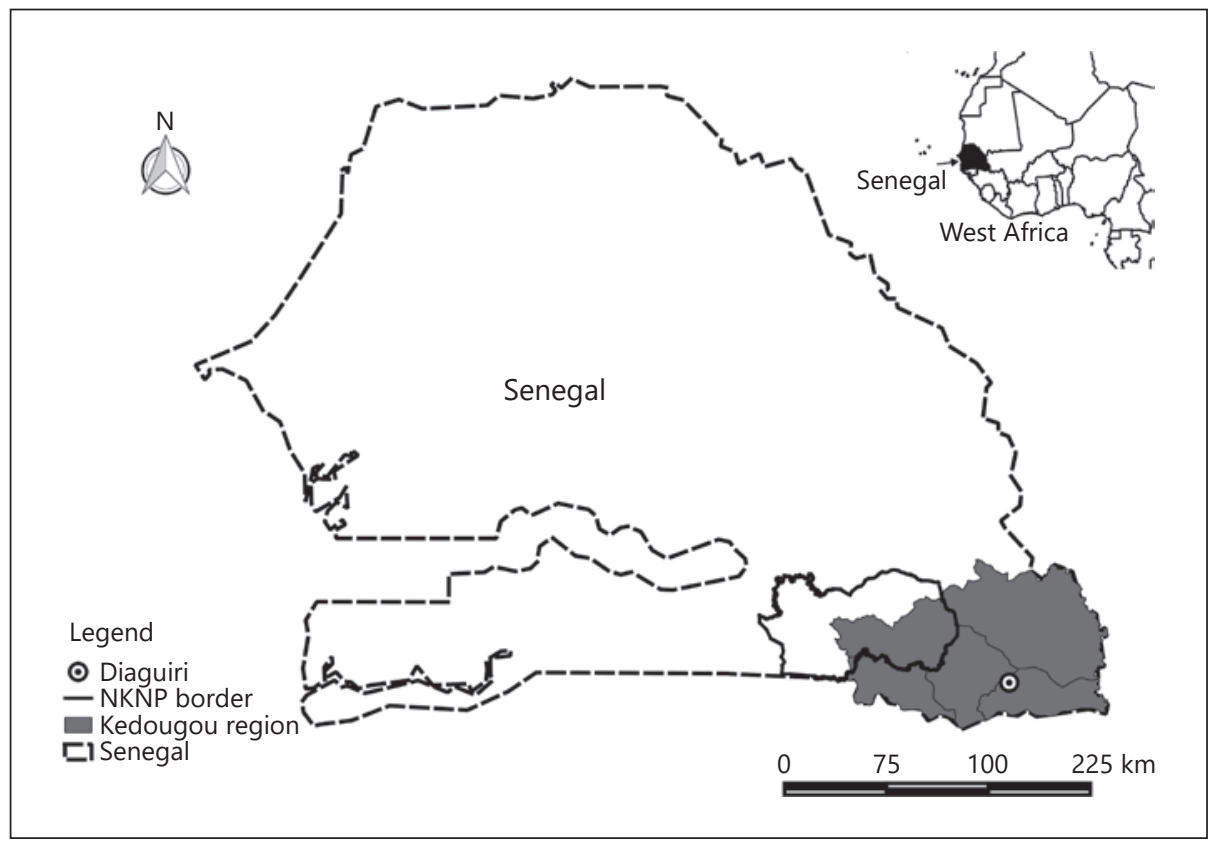

Fig. 1. Location of the study site.

Diaguiri is situated close to the city of Kedougou, a major hub within the Kedougou region (Fig. 1,2). The local human population is largely unaware of the importance of chimpanzees and their conservation [Ndiaye P.I., unpubl. observations]. Agricultural practices, hunting, poaching and gold mining are potential threats to the conservation of chimpanzees and their habitats at Diaguiri, similar to other areas of the species' range across Africa [Kormos et al., 2004]. Today, the local human population of Diaguiri is composed mainly of Muslims who do not eat primates, but the hunting of other wild animals constitutes a threat to the chimpanzees [Carter et al., 2003; Boyer-Ontl and Pruetz, 2014]. The Diaguiri chimpanzee community has at least 11 individuals, based on camera trap images of identified chimpanzees and on the maximum number of fresh nests located at a single site on the same day [Ndiaye P.I., unpubl. data].

Data Collection and Analysis

Nesting data were collected during 14 months from March 2015 to June 2016. We conducted foot surveys along recce transects in habitats that were likely to have nesting tree species, namely woodland and forest habitats [Kühl et al., 2008]. We surveyed a total transect distance of $43 \mathrm{~km}$ within a $68-\mathrm{km}^{2}$ area. We recorded the geographic coordinates, date and time for each encounter with a chimpanzee nest or a group of nests. In addition, for each nest we recorded the habitat type, supporting tree species, tree height, height of nest from the ground and nest age class. Height was measured with a Tracker 670 laser rangefinder $(n=393$ trees, mean $\pm \mathrm{SD}=$ $13.91 \pm 2.5$ ). Following Tutin and Fernandez [1984], nest age class was identified as fresh, recent, old or rotted. Fresh nests were judged to be used the night before and were identified by the presence of entirely green and unwilted leaves, with fresh faeces and/or urine sometimes present. Recent nests had wilted leaves that remained green. Old nests had a mixture of brown and dried green leaves, or consisted entirely of brown leaves. Rotted nests ranged from showing disintegrating brown leaves to leafless structures with only the supporting branches remaining. Ground nests were not observed in our study area. 


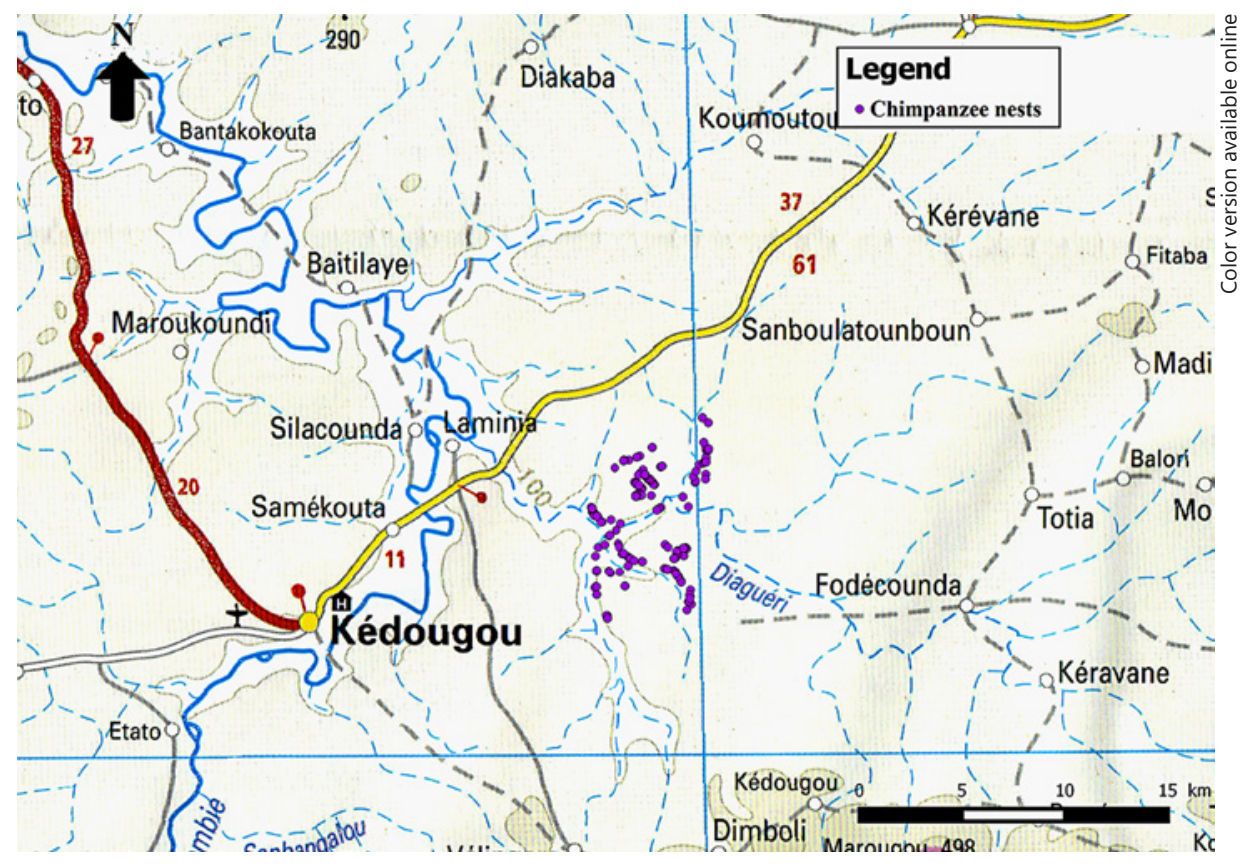

Fig. 2. Map of the study site and distribution of observed chimpanzee nests.

To assess the availability of nesting tree species and species preference by chimpanzees, we conducted vegetation surveys at nesting sites and along the recce transects. We identified and recorded all trees with a diameter at breast height $\geq 10 \mathrm{~cm}$ that could potentially support chimpanzee nests within a total of 21 quadrats each measuring $20 \times 20 \mathrm{~m}$ (each quadrat area $=400 \mathrm{~m}^{2}, 8,400 \mathrm{~m}^{2}$ total quadrat area). All quadrats were located along recce transects where chimpanzee nests had been observed. The relative abundance of each species was calculated in order to identify common and rare tree species. We tested for a preference in nesting tree species by comparing the proportion of nests in each tree species with relative abundance using a regression analysis. A tree species was considered preferred when it was used at a significantly higher rate than its relative abundance.

To determine the nest decay rate at Diaguiri, we marked a total of 109 fresh nests $(n=52$ in woodland, $n=57$ in gallery forest) and monitored each one monthly for 7 months from December 2015 to June 2016. This monitoring period began during the early-middle dry season and ended during the early wet season after the nests had completely disintegrated.

We performed statistical tests in $R$ (version 3.3.0) software to test for nesting tree preference and to evaluate the relationship between nest and tree heights using regression and correlation analyses.

\section{Results}

\section{Location of Nests and Nesting Tree Species Preference}

We recorded a total of 871 chimpanzee nests including 129 fresh (14.8\%), 128 recent (14.7\%), 398 old (45.7\%) and $216(24.8 \%)$ rotten nests. We encountered 20 nests $/ \mathrm{km}$ of transect on average. Nests were often located on the edges of gallery forests and in woodlands near tributaries of the Gambia River (Fig. 2). 


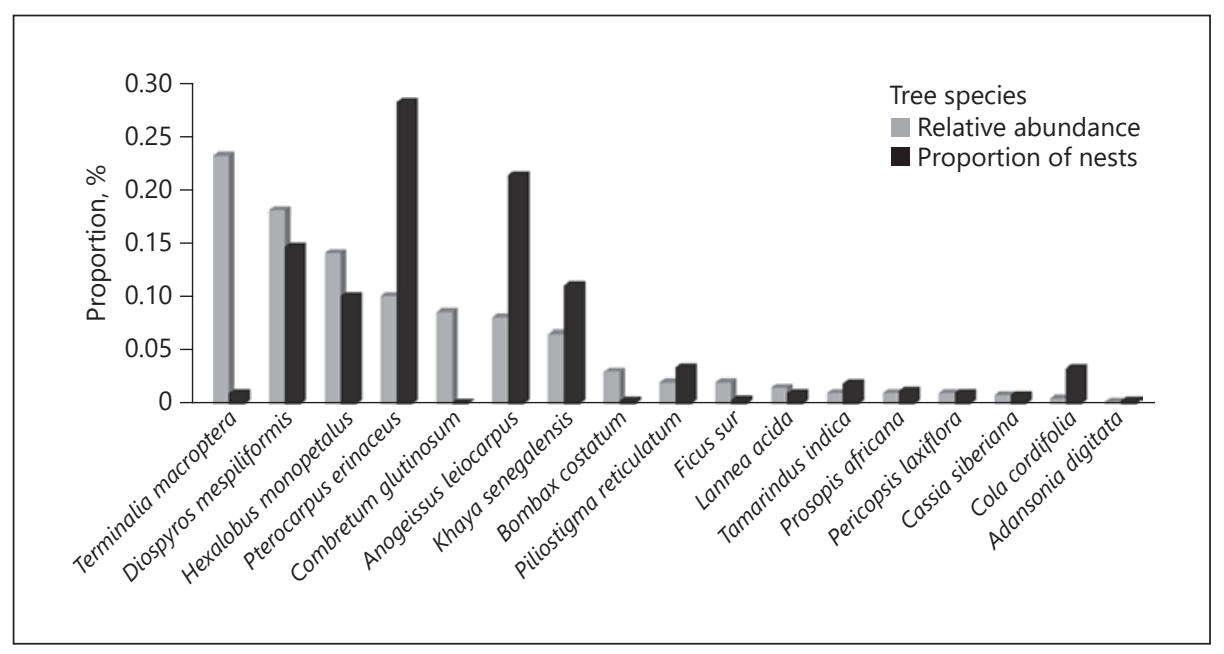

Fig. 3. Preferred tree species bearing chimpanzee nests in accordance with the abundance of the tree species in the study site.

Chimpanzees used at least 17 tree species to construct sleeping nests and $78.5 \%$ of nests were associated with 5 tree species, including the Proteacea Pterocarpus erinaceus (26.1\%), the Annonacea Anogeissus leiocarpus (19.1\%), the Dilleniacea Diospyros mespiliformis (13.6\%), the Hymenocardiacea Khaya senegalensis (10.3\%) and the Hernandiacea Hexalobus monopetalus (9.4\%). The remaining $21.5 \%$ of nests in our sample were associated with 12 other species (Fig. 3). We monitored 642 trees and vines within sample quadrats. Within this sample, we identified 40 tree species, and chimpanzee nests were observed in only 17 tree species (Fig. 3). Seven of these 40 tree species comprised $90.8 \%$ of the sample, namely Terminalia macroptera (25\%), Diospyros mespiliformis (18\%), Hexalobus monopetalus (14\%), Pterocarpus erinaceus (10\%), Combretum glutinosum (8.5\%), Anogeissus leiocarpus (8\%) and Detarium microcarpum (7.3\%). The regression analysis showed no significant relationship between trees species preference and tree species abundance $(r=0.39 ; \mathrm{df}=15 ; p=$ $0.1172)$.

\section{Nesting Height Classes}

The majority of nests were between 6 and $15 \mathrm{~m}$ above the ground (78\%). Mean nest height \pm SD was $10.9 \pm 1.7 \mathrm{~m}$ with a range of $1-15 \mathrm{~m}$. More than half of the nesting tree species $(65.5 \%)$ were $11-20 \mathrm{~m}$ in height, while a quarter of these trees were between 6 and $10 \mathrm{~m}$ (Fig. 4). These data suggest that the chimpanzees of Diaguiri have a nesting height preference, as $43.3 \%$ of nests were made within the middle of the crown. Nest height was significantly correlated with tree height $(r=0.874491, \mathrm{df}=$ 391, $p<0.001$; Fig. 5).

\section{Nest Decay Rate}

We monitored 109 of the original 129 fresh nests until they completely deteriorated (Table 1). On average, 120-130 days passed before fresh nests transitioned to 


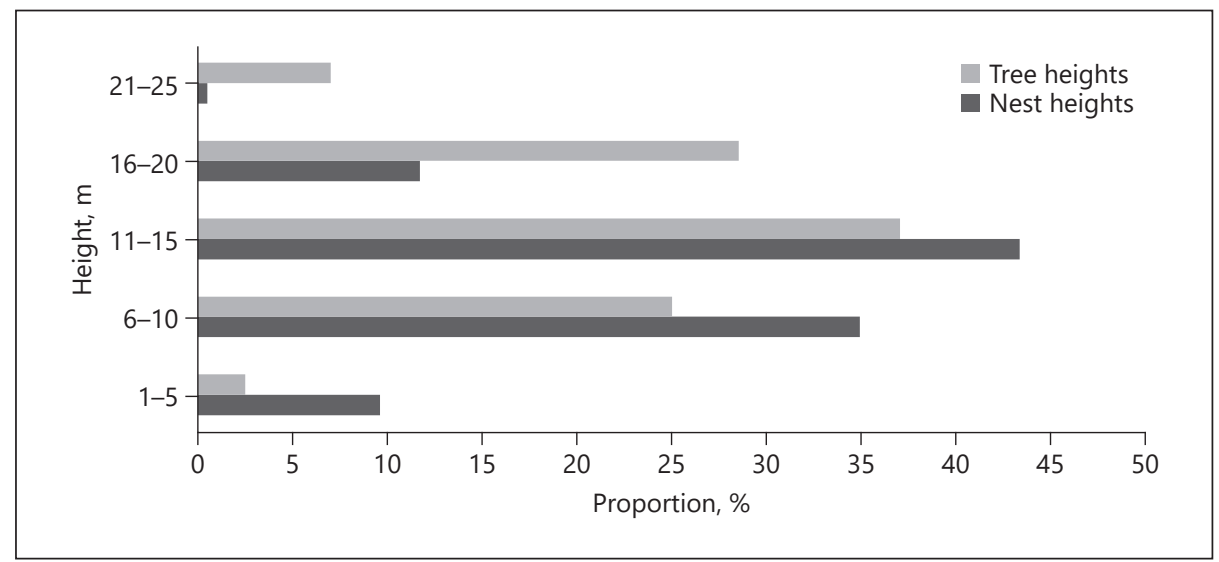

Fig. 4. Nest height classes in accordance with the height classes of the trees bearing nests.

Fig. 5. Relationship between nest height and tree height.

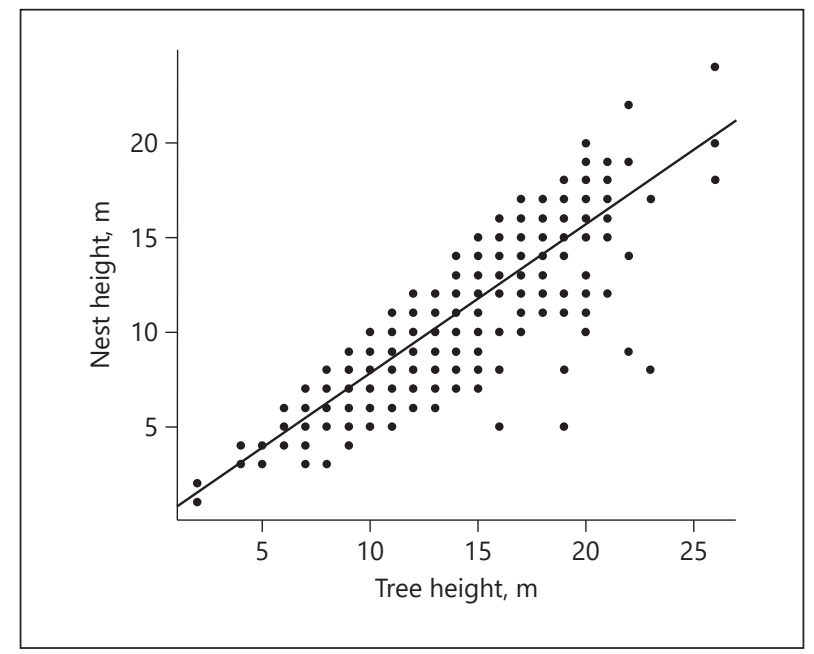

the old stage, and 176-186 days passed before a fresh nest was reclassified as rotten. The interval from fresh to rotten was shorter in gallery forests (mean \pm SD: $176.5 \pm$ 0.71 days) than in woodlands (mean: $184 \pm 2.83$ days).

\section{Discussion}

The presence of fresh and recent nests (29.5\% of total nests) during the study demonstrates that chimpanzees regularly used the Diaguiri study area. The selection of nesting site, nest height and nest-bearing trees by chimpanzees described by several authors [Basabose and Yamagiwa, 2002; Furnichi and Hashimoto, 2004; Stanford 
Table 1. Nest decay rate (number of days)

\begin{tabular}{lllllllll}
\hline Site & Localisation (UTM) & Marked & Habitat type & $\begin{array}{l}\text { Fresh } \\
\text { nest } n\end{array}$ & $\begin{array}{l}\text { Old } \\
\text { nest }\end{array}$ & $\begin{array}{l}\text { Rotting } \\
\text { nest }\end{array}$ \\
\cline { 2 - 5 } & longitude & latitude & & & & & & \\
\hline Parawol Manga 1 & 824692 & 1393692 & 30 & Woodland & 1 day & 130 days & 186 days \\
Parawol Manga 2 & 824200 & 1393551 & 24 & Gallery forest & 1 day & 120 days & 176 days \\
Diaguiri & 175121 & 1394238 & 22 & Woodland & 1 day & 124 days & 182 days \\
Diabatama & 824807 & 1391106 & 33 & Gallery forest & 1 day & 121 days & 177 days \\
\hline
\end{tabular}

The number of days indicates the time before fresh nests deteriorated to old nests or to rotting nests independent of tree species. UTM, Universal Transverse Mercator.

and O'Malley, 2008; Koops et al., 2012; Hernandez-Aguilar et al., 2013; Ndiaye et al., 2013b; Hakizimana et al., 2015] are also illustrated in the nesting behaviour of chimpanzees in Diaguiri. In this area, chimpanzees most often nested in woodland and grassland with isolated trees, while in Assirik, within the NKNP, chimpanzees nested less frequently in these habitats [Pruetz et al., 2008]. In Diaguiri, chimpanzees make their nests most often in the gallery forests, and the 5 most used nesting tree species are, in order of preference, Pterocarpus erinaceus, Anogeissus leiocarpus, Diospyros mespiliformis, Khaya senegalensis and Hexalobus monopetalus. These data provide important information for chimpanzee conservation programmes. According to the IUCN 2017 Red List of Threatened Species, K. senegalensis is a vulnerable species. $P$. erinaceus, A. leiocarpus and D. mespiliformis have not yet been assessed for the IUCN 2017 Red List but are in the catalogue of life (www.iucnredlist.org). Thus, the preference of these tree species by chimpanzees for nest building and their conservation status are good arguments for the authorities responsible for managing natural resources to revise the laws. The exploitation of these tree species in Senegal is permissible today (see www.eaux-forets.sn) and must be a threat to the conservation of chimpanzees in this region. Analysis of the abundance of the plant species likely to be selected by chimpanzee for nesting is consistent with a preference for P. erinaceus and A. leiocarpus. These two species bore about $45 \%$ of nests in our sample but represented 10 and $8 \%$ of the tree species in the study site, respectively. A similar result has been described in Kibira National Park in Burundi were most of the nests were constructed in Parinari excelsa and Carapa grandiflora, with the former being a tree species that occurred at a relatively low density ( 2 trees/ha), but bore $15.5 \%$ of all nests in this area [Hakizimana et al., 2015]. In contrast, the most abundant species (42 trees/ha), supported only $9.6 \%$ of all nests.

Nesting behaviour is associated with the physical characteristics of nesting trees. Nest and tree heights are positively correlated. The chimpanzees of Diaguiri show nesting height preferences. Nest height was significantly lower than the mean height of nesting trees. Diaguiri chimpanzees built most of their nests between 6 and $15 \mathrm{~m}$ height, below the top of the nesting tree crown. Thus, nest heights in Diaguiri (mean height = $10.9 \mathrm{~m}$ with a range of 1-25 m) exhibit some differences from Fongoli and Mont Assirik, Senegal [Pruetz et al., 2008]. Chimpanzees at Fongoli nest lower in trees (mean nesting height $=8.6 \mathrm{~m}$ ). In Assirik, the mean nesting height was $13.55 \pm 4 \mathrm{~m}$. Pruetz et 
al. [2008] think that the absence of predators in Fongoli accounts for the differences in nesting heights. Mean nest height is $12.11 \mathrm{~m}$ at Kibira National Park in Burundi, and the majority of nests occurred between 5 and $15 \mathrm{~m}$ in height [Hakizimana et al., 2015]. According to most authors, most nests are built in the middle segment of the crown [e.g., Hernandez-Aguilar, 2006; Koops et al., 2012; Hakizimana et al., 2015].

Nest decay rate varies with great ape species, nesting tree species, forest type and abiotic parameters such as rainfall, altitude, temperature, soil type and $\mathrm{pH}$ [Buij et al., 2003; Ancrenaz et al., 2004; Walsh and White, 2005; Marshall et al., 2006; Kühl et al., 2008; Mathewson et al., 2008]. The nest decay rate is 91.22 days at Taï (Côte d'Ivoire) [Kouakou et al., 2009], 90 days at Goualougo (Congo) [Morgan et al., 2006], 111 days in Kibale (Uganda) [Plumptre et al., 2003], 106 days at Lopé (Gabon) and 114 days at Belinga (Gabon) [Kühl et al., 2008], 221 days at Fouta Djallon (Guinea Conakry) [Kühl et al., 2008], 293.9 days in Guinea-Bissau [Carvalho et al., 2013] and in Issa (Ugalla, Tanzania) 139.2 days in woodland and 118 days in gallery forest [Stewart et al., 2011]. We report for the first time nest decay rates for Senegal. In the dry season, nests transition from fresh to old in about 4 months and become rotten at about 6 months after they have been first constructed. Furthermore, we found a slight difference in the nest decay rate between woodland and gallery forest. Nest decay rate is lower in woodland and higher in gallery forest. This difference could be associated with differences in nesting tree species between habitats, as A. leiocarpus and P. erinaceus occurred more often in woodland, and Mytragina inermis and D. mespiliformis were found more often in gallery forest. More research is needed in order to evaluate this hypothesis. In addition, all of the nests in our sample fully disintegrated after the rainy season, likely due to the forces of the rain and wind.

\section{Conclusion}

This work provides the first data on chimpanzee nesting behaviour and ecology in Diaguiri. In this site, chimpanzee nests are often located on the edge of gallery forests and in woodlands near tributaries of the Gambia River. Chimpanzees use at least 17 plant species to construct sleeping nests but 3 of them, namely Pterocarpus erinaceus, Anogeissus leiocarpus and Diospyros mespiliformis, are most used. They prefer to build nests within the middle of the crown. New data on nest decay rate are also provided. Nest decay rate is faster in gallery forests than in woodland habitats. Also, nest height is significantly correlated with tree height in Diaguiri, and the mean height in this site is $10.9 \mathrm{~m}$. We think that these data are very useful for managing the habitat of the Critically Endangered subspecies of chimpanzee and to inform a local action plan for the conservation and management of the savanna chimpanzee.

\section{Acknowledgements}

We thank the Ministère de l'Enseignement Supérieur et de la Recherche Scientifique du Sénégal who provided funding for this work through the FISRT programme, the local populations of Diaguiri and the Department of Eaux et Forêts of Kedougou. We would like to thank Cheikh Loucoubar and Maryam Diarra of the Groupe de Biostatistique, bio-informatique et modélisation, Institut Pasteur, Dakar, for their help with the statistical analysis. 


\section{Disclosure Statement}

There are no conflicts of interest.

\section{References}

Agence Nationale de l'Aviation Civile et de la Météorologie du Sénégal (ANACIM) (2015). Données climatiques de la region de Kédougou de 1985 à 2014.

Ancrenaz M, Calaque R, Lackman-Ancrenaz I (2004). Orang-utan (Pongo pygmaeus) nesting behaviour in disturbed forest (Sabah, Malaysia): implications for nest census. International Journal of Primatology 25: 983-1000.

Badji L, Ndiaye PI, Lindshield SM, Ba CT, Pruetz J (2018). Savanna chimpanzee (Pan troglodytes verus) nesting ecology at Bagnomba (Kedougou, Senegal). Primates 59: 235-241.

Basabose AK, Yamagiwa J (2002). Factors affecting nesting site choice in chimpanzees at Tshibati, KahuziBiega National Park: influence of sympatric gorillas. International Journal of Primatology 23: 263282.

Boyer-Ontl K, Pruetz JD (2014). Giving the forest eyes: the benefits of using camera traps to study unhabituated chimpanzees (Pan troglodytes verus) in Southeastern Senegal. International Journal of Primatology 35: 881-894.

Brownlow AR, Plumptre AJ, Reynolds V, Ward R (2001). Sources of variation in the nesting behavior of chimpanzees (Pan troglodytes schweinfurthii) in the Budongo forest, Uganda. American Journal for Primatology 55: 49-55.

Buij R, Singleton I, Krakauer E, van Schaik CP (2003). Rapid assessment of orangutan density. Biological Conservation 114: 103-113.

Carter J, Ndiaye S, Pruetz J, McGrew WC (2003). Senegal. In West African Chimpanzees: Status Survey and Conservation Action Plan (Kormos R, Boesch C, Bakarr MI, Butynski TM, eds.), pp 31-39. Gland, IUCN - World Conservation Union.

Carvalho IS (2014). Conservation Status of the Endangered Chimpanzee (Pan troglodytes verus) in Lagoas de Cufada National Park (Republic of Guinea-Bissau). PhD thesis, Universidade de Lisboa.

Carvalho JS, Marques TA, Vicente L (2013). Population status of Pan troglodytes verus in Lagoas de $\mathrm{Cu}$ fada National Park, Guinea-Bissau. PLoS One 8: e71527.

Carvalho JS, Meyer CF, Vicente L, Marques TA (2015). Where to nest? Ecological determinants of chimpanzee nest abundance and distribution at the habitat and tree species scale. American Journal of Primatology 77: 186-199.

Dutton P, Moltchanova E, Chapman H (2016). Nesting ecology of a small montane population of the $\mathrm{Ni}$ gerian/Cameroon chimpanzee (Pan troglodytes ellioti) in Nigeria. Folia Primatologica 87: 361-374.

Furnichi T, Hashimoto C (2004). Botanical and topographical factors influencing nesting-site selection by chimpanzees in Kalinzu forest, Uganda. International Journal of Primatology 25: 755-764.

Hakizimana D, Huynen M-C (2013). Chimpanzee (Pan troglodytes schweinfurthii) population density and abundance in Kibira National Park, Burundi. Pan Africa News 20: 16-19.

Hakizimana D, Buckers AH, Brotcorne F, Huynen M-C (2015). Characterization of nest sites of chimpanzees (Pan troglodytes schweinfurthii) in Kibira National Park, Burundi. African Primates 10: 1-12.

Hernandez-Aguilar RA (2006). Ecology and Nesting Pattern of Chimpanzees (Pan troglodytes) in Issa, Ugalla, Tanzania. PhD thesis, University of Southern California, Los Angeles.

Hernandez-Aguilar RA (2009). Chimpanzee nest distribution and site reuse in a dry habitat: implications for early hominin ranging. Journal of Human Evolution 57: 350-364.

Hernandez-Aguilar RA, Moore J, Stanford CB (2013). Chimpanzee nesting patterns in savanna habitat: environmental influences and preferences. American Journal of Primatology 75: 979-994.

Hoogveld J (2013). Using Field Data Collected by Local People to Expand the Knowledge of a Large Chimpanzee (Pan troglodytes verus) Population in the Boé Region of Guinea Bissau. MSc thesis, Radbond University, Nijmegen.

Humle T, Boesch C, Campbell G, Junker J, Koops K, Kuehl H, Sop T (2016). Pan troglodytes ssp. verus (errata version published in 2016). The IUCN Red List of Threatened Species 2016: e. T15935A102327574. http://dx.doi.org/10.2305/IUCN.UK.2016-2.RLTS.T15935A17989872.en (accessed June 16, 2018).

Koops K, McGrew WC, De Vries H, Matsuzawa T (2012). Nest-building by chimpanzees (Pan troglodytes verus) at Seringbara, Nimba Mountains: antipredation, thermoregulation, and antivector hypotheses. International Journal of Primatology 33: 399-401.

Kormos R, Boesch C (2003). Regional Action Plan for the Conservation of Chimpanzees in West Africa. IUCN/SSC Action Plan. Washington, Conservation International. 
Kormos R, Boesch C, Bakarr MI, Butynski T (2004). West African Chimpanzees. Status Survey and Conservation Action Plan. Gland, IUCN/SSC Primate Specialist Group.

Kouakou CY, Boesch C, Kuehl H (2009). Estimating chimpanzee population size with nest counts: validating methods in Taï National Park. American Journal of Primatology 71: 447-457.

Kühl H, Maisels F, Ancrenaz M, Williamson EA (2008). Best Practice for Surveys and Monitoring of Great Ape Population. Gland, IUCN SSC Primate Specialist Group.

Kühl HS, Sop T, Williamson EA, Mundry R, Brugiere D, Campbell G, Cohen H, Danquah E, Ginn L, Herbinger I, Jones S, Junker J, Kormos R, Kouakou CY, N’goran PK, Normand E, Shutt-Phillips K, Tickle A, Vendras E, Welsh A, Wessling EG, Boesch C (2017). The Critically Endangered western chimpanzee declines by $80 \%$. American Journal of Primatology 79: 1-15.

Marshall AJ, Nardiyono L, Engstrom M, Pamungkas B, Palapa J (2006). The blowgun is mightier than the chainsaw in determining population density of Bornean orang-utans in the forests of East Kalimantan. Biological Conservation 129: 566-578.

Mathewson PD, Spehar SN, Meijaard E, Nardiyono L, Purnomo, Sasmirul A, Sudiyanto, Oman, Sulhnudin, Jasary, Jumali, Marshall AJ (2008). Evaluating orangutan census techniques using nest decay rates: implications for population estimates. Ecological Applications 18: 208-221.

McGrew WC (2017). Field studies of Pan troglodytes reviewed and comprehensively mapped, focusing on Japan's contribution to cultural primatology. Primates 58: 237-258.

Morgan D, Sanz S, Onononga JR, Strindberg S (2006). Ape abundance and habitat use in the Goualougo Triangle, Republic of Congo. International Journal of Primatology 27: 147-179.

Ndiaye PI, Galat G, Galat-Luong A, Nizinski G (2013a). Note on the seasonal use of lowland and highland habitats by the West African chimpanzee Pan troglodytes verus (Schwarz, 1934) (Primates: Hominidae): implications for its conservation. Journal of Threatened Taxa 5: 3697-3700.

Ndiaye PI, Galat-Luong A, Galat G, Nizinski G (2013b). Endangered West African chimpanzees Pan troglodytes verus (Schwarz, 1934) (Primates: Hominidae) in Senegal prefer Pterocarpus erinaceus, a threatened tree species, to build their nests: implications for their conservation. Journal of Threatened Taxa 5: 5266-5272.

Ndimuligo SA (2007). Assessment of Chimpanzee (Pan troglodytes) Population and Habitat in Kwitanga Forest, Western Tanzania. MSc thesis, University of Witwatersrand.

Oates JF, Tutin CEG, Humle T, Wilston ML, Baillie JEM, Balmforth Z, Blom A, Boesch C, Cox D, Davenport T, Dunn A, Dupain J, Duvall C, Ellis CM, Farmer KH, Gatti S, Greengrass E, Hart J, Herbinger I, Hicks C, Hunt KD, Kamenya S, Maisels F, Mitani JC, Moore J, Morgan BJ, Morgan DB, Nakamura M, Nixon S, Plumptre AJ, Reynolds V, Stokes EJ, Walsh PD (2008). Pan troglodytes. In IUCN 2012. IUCN Red List of Threatened Species. Version 2012.2. www.iucnredlist.org (accessed February 2017).

Ogawa H, Idani G, Moore J, Pintea L, Hernandez-Aguilar A (2007). Sleeping parties and nest distribution of chimpanzees in the savanna woodland, Ugalla, Tanzania. International Journal of Primatology 28: 1397-1412.

Ogawa H, Yoshikawa M, Idani G (2014). Sleeping site selection by savanna chimpanzees in Ugalla, Tanzania. Primates 55: 269-282.

Plumptre AJ, Cox D, Mugume S (2003). The Status of Chimpanzees in Uganda. Albertine Rift Technical Report Series No 2. Wildlife Conservation Society.

Pruetz JD, Fulton SJ, Marchant LF, McGrew WC, Schiel M, Waller M (2008). Arboreal nesting as antipredator adaptation by savanna chimpanzees (Pan troglodytes verus) in southeastern Senegal. American Journal of Primatology 70: 393-401.

Pruetz JD, Marchant LF, Arno J, McGrew WC (2002). Survey of savanna chimpanzees (Pan troglodytes verus) in Southeastern Senegal. American Journal of Primatology 58: 35-43.

Stanford CB, O'Malley RC (2008). Sleeping tree choice by Bwindi chimpanzees. American Journal of Primatology 70: 642-649.

Stewart FA, Piel AK, McGrew WC (2011). Living archaeology: artefacts of specific nest site fidelity in wild chimpanzees. Journal of Human Evolution 61: 388-395.

Stewart FA, Pruetz JD, Hansell MH (2007). Do chimpanzees build comfortable nests? American Journal of Primatology 69: 930-939.

Tutin CEG, Fernandez M (1984). Nationwide census of gorilla (Gorilla g. gorilla) and chimpanzee (Pan $t$. troglodytes) populations in Gabon. American Journal of Primatology 6: 313-336.

Ukpong EE, Jacob DE, Ibok PB, Nelson I (2013). Nest building behavior of chimpanzee (Pan troglodytes Blumenbach, 1799) at Filinga Range of Gashaka Gumti National Park, Nigeria. ARPN Journal of Science and Technology 3: 714-717.

Walsh PD, White LJT (2005). Evaluating the steady state assumption: simulations of gorilla nest decay. Ecological Applications 15: 1342-1350. 